\title{
Effectiveness of bail-out mechanisms in the Eurozone: global vs. pandemic crisis'
}

\section{Ефективност „,bail-out" механизма у Еврозони: глобална vs. пандемијска криза}

\author{
Marina Beljić * \\ PhD student, University of Novi Sad, Faculty of Economics in Subotica, Subotica, Republic of Serbia, \\ marinabeliic.ef@gmail.com \\ Olgica Glavaški \\ University of Novi Sad, Faculty of Economics in Subotica, Subotica, Republic of Serbia, \\ olgica.glavaski@ef.uns.ac.rs
}

\begin{abstract}
This paper analyses the effectiveness of bail-out mechanisms after the global crisis in comparison to Covid-19 pandemic crisis in the selected Eurozone economies. It seems that in the circumstances of global instability, laissesz-faire rules in economy are not enough, meaning that government interventions are desirable and unavoidable. In the Eurozone, the implementation of bail-out programs is related with the problem of a new "impossible trinity" and no-bail out clause. However, the adopted clause on non-use of the bail-out mechanism has had to be ignored several times in the past, and those implementations of bail-outs are focus of this paper. The research is based on descriptive statistical analysis and fixed panel model specification using available data in relation to the bail-out programs in the period 2011-2020 in selected Eurozone economies. The research shows that governments appear to have learned at least three lessons from the global crisis in relation to the bail-out mechanisms: (a) the need for quick implementation of emergency measures, (b) the bail-out mechanism was effective in reducing the fiscal deficit, however, caused an increase in the public debt, and (c) strengthening the fiscal framework of the Eurozone economies by defining supranational fiscal rules remains the essence of a stronger Eurozone and the European Union.
\end{abstract}

Keywords: bail-out, global crisis, pandemic crisis, Eurozone economies

JEL classification: G38, E44, H12, H60

Сажетак: Овај рад анализира ефективност механизама спасавања након глобалне кризе у поређењу са пандемијом Ковид-19 у економијама Еврозоне. Чини се да у околностима глобалне нестабилности laissesz-faire правила у економији нису довољна, што значи да су интервенције влада пожељне и неизбежне. У Еврозони је примена програма спасавања повезана са проблемом новог „немогућег тројства“ и клаузуле о забрани коришћења bail-out механизма. Међутим, усвојена клаузула о некоришћењу bail-out механизма морала је у прошлости бити игнорисана неколико пута, а управо те имплементације програма спасавања представљају фокус овог рада. Истраживање се заснива на

${ }^{1}$ The previous version of the paper has been presented at the 26th International Scientific Conference Strategic Management and Decision Support Systems in Strategic Management, Subotica, May $21^{\text {st }}$ 2021.

Corresponding author 
дескриптивној статистичкој анализи и на фиксној спецификацији модела панела базираној на доступним подацима у вези са програмима спасавања у периоду 2011-2020. одабраних економија Еврозоне. Истраживање показује да су владе научиле најмање три лекције из глобалне кризе, а поводом програма спасавања: (а) потреба за брзом применом хитних мера, (б) механизам спасавања био је ефикасан у смањењу фискалног дефицита, међутим, утицао је на раст јавног дуга и (ц) јачање фискалног оквира економија Еврозоне дефинисањем наднационалних фискалних правила остају суштина снажније Еврозоне и Европске уније.

Кључне речи: Bail-out, глобална криза, пандемијска криза, економије Еврозоне JEЛ класификација: G38, E44, H12, H60

\section{Introduction}

This paper analyses the effectiveness of bail-out mechanisms after the global crisis in comparison to Covid-19 pandemic crisis in the selected Eurozone economies. It seems that in the circumstances of global instability, laissesz-faire rules in economy are not enough, meaning that government interventions are desirable and unavoidable. A bail-out is one of the government mechanisms with the aim to provide financial help and to protect financial system of a country (or corporation) which otherwise would be on the brink of failure or bankruptcy. In the Eurozone, the implementation of bail-out programs is not related only to the costs and consequences of bail-out programs, but also to "impossible trinity". Namely, the "new impossible trinity" is related to fiscal sovereignty, monetary union (independent monetary policy) and no-bail-out clause, meaning difficulties for the Eurozone decisionmakers to implement bail-out programs. However, the adopted clause on non-use of the bail-out mechanism has had to be ignored several times in the past. The subject of this research is the success of implemented bail-out programs, primarily in the period after the global financial and debt crisis, and thereafter, the benefits of activating the bail-out mechanism as a cure for the pandemic crisis are examined. The research is based on descriptive statistical analysis using available data in relation to bail-out programs in the period 2011-2020 and on panel data model for implemented bail-out programs in the period 2011-2019 in the selected Eurozone economies.

The effectiveness of the bail-out mechanism is reflected in the results achieved in the countries that responded to the crisis of 2008 with aid packages, both from national budgets and European Union (EU) funds. Those countries are the PIGS countries (Portugal, Ireland, Greece, Spain) plus Cyprus, which had different initial conditions and space for government intervention, but what they have in common is the need for a bail-out mechanism. Bail-out programs involved sacrifices and painful reforms, which forced states to give up their long-standing ideals, more precisely, welfare states. The crisis caused by the Covid-19 pandemic is very different from previous crises. Economies are faced with a non-economic shock which soon generated a combination of economic shocks on both the supply and demand sides. The simultaneity gives strength and severity to the pandemic crisis. In the current inclinations, economic policy makers are forced to intervene more than ever before. Such circumstances lead to additional government borrowing, i.e. an increase in the public debt, which directly leads to an increase in risk, especially in over-indebted countries. 
Taking into account genesis and effects of global and pandemic crisis, the goal of this paper is twofold: (1) to analyse the diversity of bail-out programs implemented in global vs. pandemic crisis; (2) to analyse the effectiveness of bail-out mechanisms after the global crisis using panel models in comparison to Covid-19 pandemic crisis in selected Eurozone economies. Main hypothesis could be summarized as follows. H1: the bail-out mechanisms have negative influence on the fiscal deficit (fiscal deficit decreases) and positive on public debt (public debt increases). H2: policymakers of the Eurozone have learned some lessons from the global crisis and applied them in a pandemic crisis.

The remainder of the paper is organized as follows. After the introduction, Section 1 reviews existing evidence in the literature in relation to bail-out mechanisms. Section 2 discusses the nature of the emergence of the global financial crisis vs. the crisis caused by the pandemic. Section 3 analyses the effectiveness of the application of the bail-out mechanism primarily after the global crisis using panel model with fixed effects, thereafter the aid packages extorted by Covid-19. Concluding remarks are pointed out in the last section.

\section{Literature review}

Causes and effects of the global crisis have been issues of vigorous debate in the world, and particularly in EU economies. A number of comparative empirical approaches were used in trying to explain global crisis and ways to save the economy. The effects of the global financial crisis on the EU are analysed by Ullah and Parvez Ahmed (2014), emphasizing the strength of the spill-over effects on the financial market. Helleiner (2011) explains that the EU reaction - the withdrawal of European banks' loans from the financial market is an attempt to mitigate the consequences of the crisis. Schuknecht et al. (2011) also write about the attempt to mitigate the consequences, and they see EU fiscal federalism as a potential solution to future crises. In relation to Covid-19 crisis, exogenous health shock is defined as the source of the crisis (Didier et al. 2020). Therefore, Wilkes (2020) studied the impact of exogenous shock on the global recession, that is, it examines its severity and makes an assumption about the form of the recession. Also, Guillen (2020) is of the opinion that the form of recession cannot be predicted with accuracy, but that it is certain that the recovery will not be fast, and that economies will have to invest a lot of effort to return economic activity to the previous level. In relation to negative exogenous shocks, Beker Pucar (2020) explains that external adjustment can take place through changes in aggregate expenditure (expenditure-reducing mechanism) or changes in its composition (expenditure-switching mechanism).

Focus in this paper is related to bail-out mechanisms used in global, and later in pandemic crisis, which is in relation to the question of new "impossible trinity" in the Eurozone. Primarily, Beck and Prinz (2012) write about the reasons why it is impossible to maintain an independent monetary policy, a sovereign fiscal policy and a clause on nonusing the bail-out mechanism at the same time. The first element refers to fiscal sovereignty, i.e. the possibility for each EU member state at the national level to choose the level of public debt and fiscal deficit in relation to GDP, without any interference and 
restrictive policies of other EU member states. The second element is an independent monetary policy that has been transferred to the supranational level, with the establishment of the supranational central bank of the ECB and the establishment of a monetary union (EMU). The focus of EMU is to achieve price stability, and financing public debt by printing money is completely prohibited. The third element is a bail-out agreement. The nobail-out clause ensures that the public debt of one member state cannot be financed by other EU members that are in a better position, i.e. there is no obligation to save countries that pursue bad fiscal policies. The "impossible trinity" is especially pronounced in crisis situations when there is a large increase in fiscal deficits and indebtedness.

Moreover, this paper deals with the literature that studies the efficiency of the bailout mechanism in global and pandemic crisis. Although all Eurozone countries were affected by the global crisis, the most exposed countries were the Eurozone periphery countries (PIGS). Therefore, resolving the public debt problem of Greece was raised on a supranational level using bail-out mechanisms (Kickert \& Ongaro, 2019). Schuknecht et al. (2011) write about the justification of using the bail-out mechanism in the PIGS countries, as a solution for unbridled public finances and growing public debt. More about bail-out programs used in Greece is written by Pagoulatos (2019). This paper discusses the effects of implemented bail-out mechanisms and the belt tightening policy that was implied through the implementation of the program. Gurnani (2016) writes about the economic and financial situation in which Portugal found itself, as well as the process of applying the bail-out mechanism, emphasizing the efficiency of the program used. McDonagh (2017) in his paper analyses the causes that led to the escalation of the fiscal deficit which spilled over into the growth of public debt in Ireland. Bagus et al. (2016) investigate state response in the form of a bail-out mechanism in Spain, using a partial bail-out program whose funds were exclusively directed to the banking sector. The authors conclude that the effectiveness of the program used in Spain is questionable. Iordanidou and Samaras (2014) provide insight into the development of the crisis in Cyprus, as well as the necessity to accept the bail-out mechanism.

In relation to the literature dealing with measures to help against the current pandemic crisis, Batini et al. (2020) argue concerning rapid and joint EU reaction in the need to unite and overcome the crisis as painlessly as possible. Glavaški and Beker Pucar (2020) also emphasize the importance of strengthening the fiscal framework, stimulating the coordination between national and supranational fiscal arrangements. Acharya et al. (2020) stress the importance of the banking system for overcoming the crisis caused by the Covid-19 pandemic. The authors point out the lesson learned from the global financial crisis. This paper fills the gap in the literature by comparing bail-out mechanisms from both crises, as well as by modelling the effects of specific bail-out programs after outburst of the global crisis.

\section{Genesis of global vs. pandemic crisis}

The problem of new "impossible trinity" has escalated in Eurozone economic during the crisis - global and pandemic crisis. The global financial crisis of 2007-2008 took place in 
several stages. The collapse was preceded by massive growth of mortgage loans in the United States, which created a financial bubble, and then the dizzying fall in real estate prices led to the bursting of the financial bubble. Consequently, there was a collapse, the market became oversaturated with securities without any cover. Securities with a high credit rating were no longer collectible. Obviously, that was where the problem arose. Banks, and thus the market, were no longer liquid. There was a collapse of the whole financial market. As economies are more connected than ever, the problem of the collapse of the financial market in the United States has become the problem of all economies at lightning speed. The domino effect and panic according to Ullah and Parvez Ahmed (2014), was felt around the world in the markets - bonds, stocks, loans. However, the repercussions of the crisis were far greater than that. Although it all started with the collapse of hedge funds, and then the largest investment banks, the crisis soon spread to the real sector. With the desire to get out of the crisis as safely as possible, according to Helleiner (2011), European banks withdrew loans from the international financial market. According to this move, the credit market almost dried up, which had a direct impact on the stagnation of imports and exports, and the prices of goods. The crisis circumstances had the strongest impact on the economies that were vulnerable even before the crisis, i.e. unstable public finances. Those are economies that have not been able to control the fiscal deficit and that have resulted in accumulated public debt.

According to Glavaški and Beker Pucar (2020), the global recession has highlighted all the shortcomings of the unfinished EU project. Hence, how did those circumstances affect the Eurozone? According to Schuknecht et al. (2011), the Eurozone has provided a range of measures in response to the financial and economic crisis, which have sought to mitigate the consequences and support economic activity. The measures were implemented through the European Economic Recovery Plan (ERP) under the auspices of the European Commission. However, the recovery did not go in the desired direction. There was an increase in the average fiscal deficit by more than 5\% of GDP, while public debt averaged almost $85 \%$ of GDP, which is more than $20 \%$ of pre-crisis levels, and more than $25 \%$ of allowed level of public debt relative to GDP. An extremely worrying fact was that, in PIGS EU countries, public debt exceeded $100 \%$ of GDP. The PIGS countries simultaneously faced an unprecedented crisis, while their access to the international financial market was denied. That meant only one thing. The non-use of bail-out clause had had to be abandoned in order to provide much-needed financial assistance to the EU members. The PIGS had different initial conditions and space for government intervention, which would mean that the range of the mechanism was different, as well as the type and time period of its use. Applying a bail-out mechanism was the alluring option, however it involved sacrifices and painful reforms, which forced states to give up their long-standing ideals, more precisely welfare states.

The crisis caused by the Covid-19 pandemic is very different from previous crises. Economies have been faced with non-economic shock which soon has generated a combination of economic shocks on both the supply and demand sides. The simultaneity gives strength and severity to the pandemic crisis. Primarily, it is crucial to understand the impact of the rate of virus spread on macroeconomics. At the very beginning of the crisis, 
due to the nature of the occurrence, i.e. exogenous shock, as Wilkes (2020) explains, many economists and politicians shared an optimistic attitude. They predicted that the crisis would have a "V" shape, and that there would be a steep decline in economic activity, which would be short-lived, and an even faster return to the pre-crisis level.

Now, just over a year after the crisis began, many researchers and economists no longer share that optimism (Guillen, 2020), moreover, the expectations are more than worrying. In relation to the further course of the crisis, and the necessity of a "lockdown", according to Didier et al. (2020), the crisis could have an "L" shape. Such scenario will happen if there are mass layoffs with the simultaneous abolition of certain jobs. The problem arises if a laid-off worker remains structurally unemployed, due to the inability to adapt quickly to market needs. Therefore, it is necessary to preserve as much as possible both the connections between economic entities and the connections between the employer and the worker, to prevent further productivity decline of market actors. In the current inclinations, economic policy makers are forced to intervene more than ever before. Macroeconomic challenges are undoubtedly great, and combined with financial needs, the crisis has been heated up. Assistance packages are key factor in maintaining links between businesses. It seems that now almost all market players are "too big to fail", because in the current circumstances it is extremely difficult to compensate for the lost market player, especially because of the sustainability/survival of economies after the exit from the pandemic crisis.

When it comes to the Covid-19 pandemic, most things are still unknown. What is certain is that changes are taking place in economic activity itself. As Didier et al. (2020) assume, the pandemic will have long-term consequences on the nature of economic activity, which would mean expansion for some sectors on the one hand, or complete collapse for others. At the same time, changes are taking place on the demand side, as consumers have had very quickly adapted their recent habits to the new circumstances. Moreover, the changes did not bypass investments either. Such circumstances lead to additional government borrowing, i.e. an increase in public debt, which directly leads to an increase in risk, especially in over-indebted countries. That is also indicated by the fact that countries are facing a drastic increase in costs on the capital market and sudden cessation of capital inflows. Intervention at the supranational level may be of particular importance to developing countries as it would avoid pro-cyclicality of measures and prevent an even deeper recession. The speed of national governments' response is crucial, as it significantly reduces the gap between the adoption of measures and their implementation once the problem has been identified.

\section{Empirical analysis of bail-out mechanisms}

\subsection{Global crisis}

Adverse circumstances on the world economic scene caused by the global financial crisis have confronted the PIGS countries with uncontrolled growth of public debt. The inability to curb public finances was also a consequence of rising costs in servicing debts, which has led to either leaving EMU or negotiating bail-out programs. The option of abandoning the 
euro would mean a return to weak national currencies, which would further open space for shackles that would deepen the already existing problem. Consequently, there are justifiable reasons why Eurozone countries have chosen to accept aid packages (Schuknecht et al. 2011). In order to enable the realization of risk sharing among EMU members, funds were established from which bail-out programs were financed. The financial support provided by the European Financial Stability Facility (EFSF) is provided by joint national guarantees in proportion to the capital participation of the European Central Bank (ECB) (Mongelli, 2013). The European Stability Mechanism (ESM) is the second fund to finance the programs; it is defined by an international agreement between the members, established as a permanent international institution with various financial instruments at its disposal. This makes it the most capitalized financial institution in the world, with an effective credit capacity of EUR 700 billion. The implementation of the programs was monitored by the Troika, which consisted of the European Commission, the International Monetary Fund (IMF) and the ECB, while users were Greece, Ireland, Portugal, Spain, and Cyprus (Table $1)$.

Table 1 Implemented bail-out programs after the global crisis

\begin{tabular}{|c|c|c|c|c|c|c|c|}
\hline Country & \begin{tabular}{|l|} 
Source of \\
Financing
\end{tabular} & Duration & Amount & Deficit BEFORE & Deficit AFTER & $\begin{array}{l}\text { Public Debt } \\
\text { BEFORE }\end{array}$ & \begin{tabular}{|l|} 
Public \\
Debt \\
AFTER \\
\end{tabular} \\
\hline Greece & $\begin{array}{l}\text { EFSF, EFSM, } \\
\text { ESM, IMF }\end{array}$ & 2011-2019 & $\begin{array}{l}256 \text { billion } \\
\text { EUR }\end{array}$ & $\begin{array}{l}-15.1 \% \text { of GDP, } \\
2009\end{array}$ & $\begin{array}{l}1.5 \% \text { of GDP } \\
2019\end{array}$ & $\begin{array}{l}142.8 \% \text { of } \\
\text { GDP, } 2010\end{array}$ & $\begin{array}{l}180.5 \% \text { of } \\
\text { GDP, } 2019\end{array}$ \\
\hline Ireland & EFSF, EFSM & $2010-2013$ & $\begin{array}{l}85 \text { billion } \\
\text { EUR }\end{array}$ & $\begin{array}{l}-32.1 \% \text { of GDP, } \\
2010\end{array}$ & $\begin{array}{l}0.5 \% \text { of GDP } \\
2019\end{array}$ & $\begin{array}{l}96.2 \% \text { of GDP, } \\
2010\end{array}$ & $\begin{array}{l}57.4 \% \text { of } \\
\text { GDP, } 2019\end{array}$ \\
\hline Portugal & $\begin{array}{l}\text { EFSF, EFSM, } \\
\text { IMF }\end{array}$ & $2011-2014$ & $\begin{array}{l}78 \text { billion } \\
\text { EUR }\end{array}$ & $\begin{array}{l}-11.2 \% \text { of GDP, } \\
2010\end{array}$ & $\begin{array}{l}0.1 \% \text { of GDP, } \\
2019\end{array}$ & $\begin{array}{l}93 \% \text { of GDP, } \\
2010\end{array}$ & $\begin{array}{l}117,2 \% \text { of } \\
\text { GDP, } 2019\end{array}$ \\
\hline Spain & ESM & $2012-2013$ & $\begin{array}{l}41.3 \text { billion } \\
\text { EUR }\end{array}$ & $\begin{array}{l}-11 \% \text { of GDP, } \\
2009\end{array}$ & $\begin{array}{l}-2.9 \% \text { of GDP, } \\
2019\end{array}$ & $\begin{array}{l}60.1 \% \text { of GDP, } \\
2010\end{array}$ & $\begin{array}{l}95.5 \% \text { of } \\
\text { GDP, } 2019\end{array}$ \\
\hline Cyprus & ESM & $2013-2016$ & $\begin{array}{l}628 \text { billion } \\
\text { EUR }\end{array}$ & \begin{tabular}{|l}
$-5.7 \%$ of GDP, \\
2009
\end{tabular} & $\begin{array}{l}1.5 \% \text { of GDP, } \\
2019\end{array}$ & $\begin{array}{l}65.9 \% \text { of GDP, } \\
2010\end{array}$ & $\begin{array}{l}94 \% \text { of } \\
\text { GDP, } 2019\end{array}$ \\
\hline
\end{tabular}

Source: The authors using database from Eurostat (2021) and Glavaški \& Beker Pucar (2020).

The public debt crisis that hit Greece in 2010 according to Kickert and Ongaro (2019) could not have been resolved nationally. Even before the outbreak of the crisis, Greece had a level of public debt that exceeded the allowed threshold of $60 \%$ of GDP (the Maastricht Treaty), therefore after the coup, it faced indebtedness that led to bankruptcy. The hopeless situation cried out for a foreign help. On the side of the helper, in addition to the IMF, there was also the ECB. Hence, in that way, the implementation of the first of a total of three bail-out programs in which Greece participated (in the period from 20112019) began. According to Pagoulatos (2019), the acceptance of first financial aid implied both harsh and strict fiscal measures. The policy of tightening the belt for the ultimate goal was the general growth of economic activity and the raising of the Greek economy. The implementation of the first bail-out program did not have the expected effects. Moreover, desired goals had not been achieved and the position of public finances was also aggravated 
by the rapid growth of public debt. Such an outcome led Greece to participate in the second bail-out program, which did not differ much from the first, except in the part in which it implied the reconstruction of the public debt. However, its fate was very similar to the first bail-out; political instability and social tensions made it impossible to implement the program to the end. The third bail-out was far more successful than the previous two. The fiscal deficit has been brought under control, a post-crisis deficit (2009) of 15\% of GDP converted into a surplus of $1.5 \%$ of GDP in 2019 (Table 1). However, there was a deterioration of public debt which continued the growth trend (from 142.8\% of GDP in 2010) and reached as much as $180.5 \%$ of GDP (in 2019). More precisely, Figure 1 shows the bail-out mechanism implemented in Greece which is funded both through EFSF and ESM. The most generous aid was provided from the EFSF of 141.8 billion, with the longest repayment term, until 2070, while the ESM repayment is planned by 2060. Figure 1 shows Greece's indebtedness according mentioned programs.

Figure 1 Bail-out and repayment of EFSF and ESM in Greece

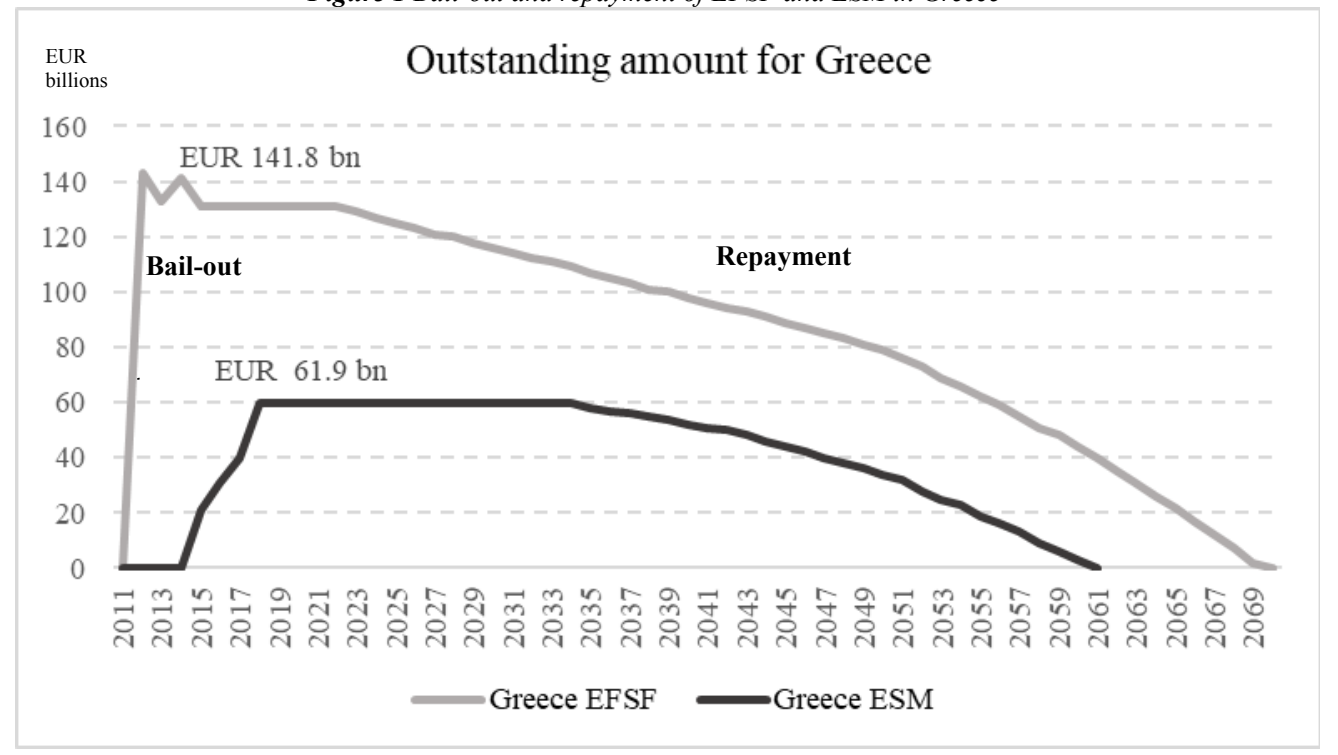

Source: The authors, using ESM data (https://www.esm.europa.eu/assistance/programme-database).

The collapse of the world financial market spilled over to Ireland in a flash, which is partly a consequence of the non-existence of a single banking system within the Eurozone. To address the illiquidity and even insolvency of banks, the Irish government has offered limited guarantees on all bank deposits and old debts. The Irish government in its stabilization of the economy and finances was guided by a philosophy of "essential importance", instead "too big to fail" (McDonagh, 2017) which soon led first to fiscal deficit escalation, then of the enormous growth of public debt. The funds needed to recruit on the front line exceeded the national government's capacity. Due to that Ireland agreed to a bail-out program (the second largest, amounting to $€ 85$ billion), which took place in nine episodes of adjustment in the period 2010-2013. According to Kickert and Ongaro (2019), 
the program contributed to the stabilization of public finances, which can be seen in the reduction of the enormous deficit from 2010 , which amounted to $32.1 \%$ of GDP, to $0.5 \%$ of GDP in 2019. Also, unlike other countries participating in the bail-out program, Ireland did not have negative consequences for the public debt, which was successfully reduced from $96.2 \%$ of GDP in 2010 to $57.4 \%$ of GDP in 2019 (Table 1). Figure 2 shows the repayment plan for Ireland, Portugal and Spain. Also, it can be seen from the figure that Spain has the shortest deadline, until 2027, for when it is foreseen that the debt will be settled. The deadline for Ireland is until 2035, while for Portugal is until 2040.

Figure 2 Bail-out and repayment of EFSF in Portugal, Ireland and Spain

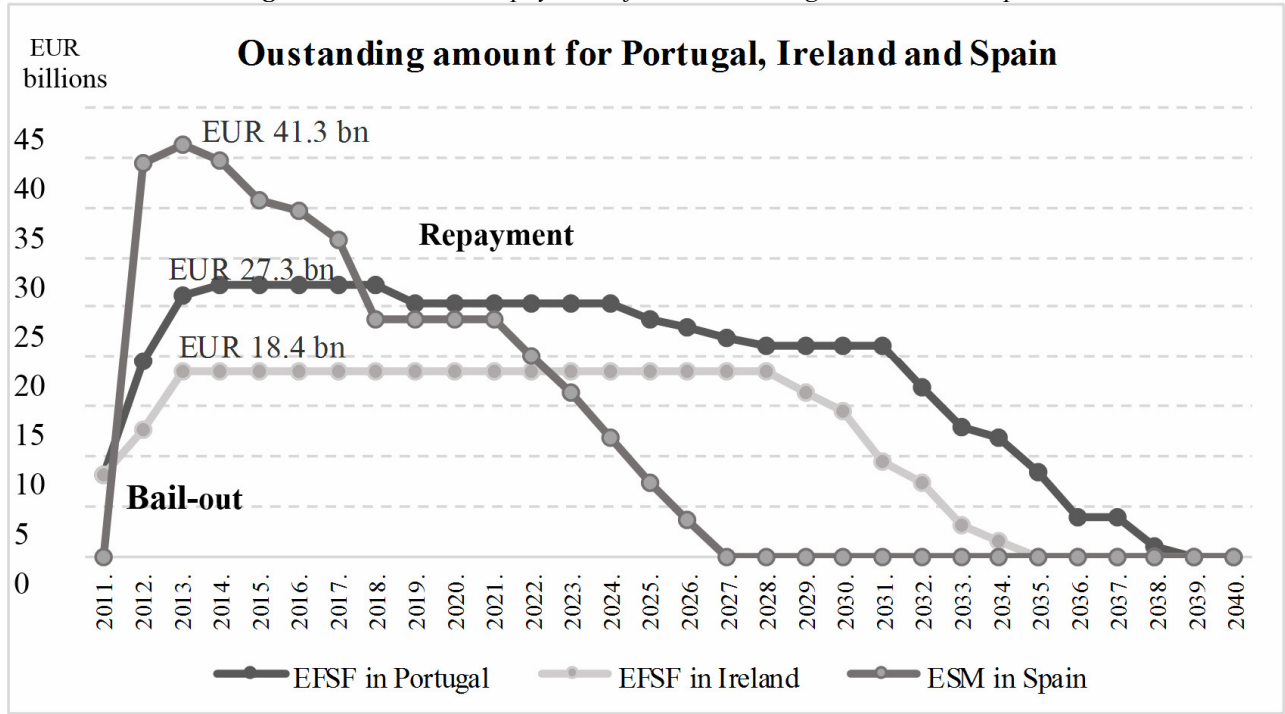

Source: The authors, using ESM data (https://www.esm.europa.eu/assistance/programme-database).

Like Greece, Portugal faced a bad economic and financial situation. Affected like that, it turned to the IMF for help. Portugal entered the bail-out process in 2011 and ran it until 2014. The volume of financial assistance provided to Portugal is almost four times less than the funds provided to Greece (EUR 78 billion). The program consisted of fiscal consolidation, fiscal stability, and structural transformation (Gurnani, 2016). In the short term, the problem of the fiscal deficit was successfully remedied, it was reduced from $9.2 \%$ of GDP (2010) to 3\% of GDP (2013), and in 2019, Portugal created a surplus of $0.1 \%$ of GDP (Table 1). In the short term, the negative consequences of the adjustment were suffered. However, in the long run, bankruptcy has been prevented in the first place, which has improved the credibility and reputation that are extremely important for operating in the capital market. Significant structural reforms have made it possible to improve the macroeconomic picture, competitiveness and economic performance. However, as with Greece, the bail-out mechanism left negative consequences on public debt, which grew from $93 \%$ of GDP in 2010 to $117.2 \%$ of GDP in 2019 (Table 1). 
The problems of the Spanish economy were mainly a consequence of the crisis in the real estate market. The crisis caused instability in the banking sector, combined with the decline in economic activity, decline in government revenues, with also significant consequences in public finances. At a moment when public debt had risen to $100 \%$ of GDP, it was clear that the Spanish government could not cope with the crisis on its own, and it sought help from the EU and the ECB. Unlike other countries, Spain applied a partial bailout program, which involved financial injections only for the banking system. It participated in the program for one year from 2012-2013, and received assistance of EUR 41.3 billion in that period. The success of the bail-out mechanism according to Bagus, Raillo \& Neira (2016) is questionable. However, the fiscal deficit has been successfully brought within the allowed limits, from $11 \%$ of GDP (2009) to $2.9 \%$ of GDP (2019). Table 1 shows that the impact on public debt is similar to that of Greece and Portugal, the implementation of aid packages has led to an increase in public debt instead of its reduction, from $20.1 \%$ of GDP (2010) to as much as $95.5 \%$ of GDP (2019).

According to Iordanidou \& Samaras (2014), the debt crisis that Cyprus experienced was one of the most complex crises within the Eurozone. Several factors are the main culprits for the escalation of the crisis, the first one was the credit boom - generous lending to households and the economy. The second factor that was the trigger is the acceptance of the euro as the official currency and the entry into the EMU, and finally, the third factor that was also a source of the global financial crisis was the bubble in the real estate market. The crisis in Cyprus took place in three phases. In the first phase the overflowing effects of the global financial crisis were immediately felt in Cyprus, considering the indebtedness of the population and the economy, and the connection of the financial market of Cyprus with the world financial market. In a circular phase, in the period from 2008-2011, Cyprus was denied access to the international capital market. In the third phase, due to the bad assessment of the country's credit rating, Cyprus had no choice but to negotiate a bail-out mechanism, which, as in previous countries, meant significant measures and cuts in addition to financial assistance. Hence, in absolute terms, Cyprus received 6.28 billion euros in financial assistance. With these funds, the fiscal deficit was successfully reduced from $5.7 \%$ of GDP in 2012, and in 2019 a budget surplus of $1.5 \%$ of GDP was recorded. However, as with other members except Ireland, the bail-out mechanism has affected public debt growth from $65.9 \%$ of GDP in 2012 to as much as 94\% of GDP in 2019 (Table 1).

Although Table 1 shows the sources of finance, as well as the amount of bail-out (from the highest to the lowest amounts of program), the important part of the table is related to the effects of bail-out programs on fiscal deficit and public debt. From the empirical data, it could be concluded that activating the bail-out mechanism has a beneficial effect on reducing the budget deficit for all observed economies, however, has a negative impact on public debt for most of them (except Ireland). Correlation coefficient as well indicated negative relationship between bail-out and fiscal deficit (-0.2562) and positive between bail-out and public debt (0.6127). In order to check significance of this relationship, balanced panel data model for the five economies which have been used bailout programs (Greece, Ireland, Portugal, Spain and Cyprus) in the period 2011-2019 has 
been estimated. The choice of the model that best fits analysed data is determined by the sample and potential variability across the time and economies (time vs. individual effects).

Classical panel data models are Fixed Effects (FE) and Random Effects (RE) panel specifications, with individual and/or time effects. In order to find out whether significant variability in cross-section dimension (individual effects) and in time dimension (time effects) exists, we used Anova F-test and Welch F-test (Table 2). The results indicate that there is a significant difference between cross-section observations, which is not the confirmed for the time dimension (except in variable fiscal deficit). Therefore, specification should be with individual effects; however, the question is whether fixed or random specification.

Table 2 Variability in cross-section and time dimensions

\begin{tabular}{|c|c|c|c|c|c|c|c|c|}
\hline \multirow{3}{*}{ Variables } & \multicolumn{4}{|c|}{$\begin{array}{l}\text { Variability testing in cross-section } \\
\text { dimension }\end{array}$} & \multicolumn{4}{|c|}{ Variability testing in time dimension } \\
\hline & \multicolumn{2}{|c|}{ Anova F-test } & \multicolumn{2}{|c|}{ Welch F-test } & \multicolumn{2}{|c|}{ Anova F-test } & \multicolumn{2}{|c|}{ Welch F-test } \\
\hline & Coef. & p-value & Coef. & $\begin{array}{l}\mathrm{p}- \\
\text { value }\end{array}$ & Coef. & p-value & Coef. & $\begin{array}{l}\mathrm{p}- \\
\text { value }\end{array}$ \\
\hline Bailout & 11.89 & 0.000 & 3.65 & 0.024 & 0.568 & 0.786 & 0.667 & 0.898 \\
\hline Fiscal deficit & 0.544 & 0.003 & 0.766 & 0.059 & 12.170 & 0.000 & 9.771 & 0.000 \\
\hline Public debt & 61.44 & 0.000 & 146.4 & 0.000 & 0.132 & 0.997 & 0.113 & 0.998 \\
\hline Interest & 5.716 & 0.001 & 8.255 & 0.001 & 2.172 & 0.536 & 2.892 & 0.036 \\
\hline
\end{tabular}

We estimated two models, first, with fiscal deficit as dependent variable, and the second one with public debt as dependent variable, using both specifications, FE and RE. Initially, all potential explanatory variables were included in the model (bail-out, interest, public expenditure, public revenues, GDP per capita), and econometric procedure "from general to specific" is used to eliminate insignificant regressors. In order to decide between FE and RE specifications, we used Hausman test analysing whether the error is correlated with regressors. The results of Hausman test indicated that preferable specification is FE model with individual effects (Table 3).

Table 3 Bail-out effects on fiscal deficit and public debt

\begin{tabular}{|l|ll|l|l|l|l|l|}
\hline \multicolumn{3}{|c|}{$\begin{array}{c}\text { Model 1 } \\
\text { Dependent variable: fiscal deficit }\end{array}$ (share in GDP) } & \multicolumn{4}{c|}{ Model 2 } \\
Dependent variable: public debt (share in GDP)
\end{tabular}

Note: FE and RE specifications contain individual effects, and no time effects. Source: Authors' estimations.

The results (Table 3, Model 1) showed that variables related to bail-out mechanisms and interest were the most important in explaining fiscal deficit (only significant variables are presented in the model). Variable bail-out is significant with 
expected sign in explaining fiscal deficit (-5.21): a growth of bail-out programs decreases fiscal deficit. The model showed that growth of public debt servicing, namely interest payments, indicated fiscal deficit deterioration (2.913). On the other hand, the results of Model 2 (Table 3) showed that bail-out is significant in determining public debt, namely, that growth of bail-out programs increases public debt (2.39). Interest as well determine public debt significantly, with positive sign.

According to the estimated models, we could confirm the analysed hypothesis, namely, the bail-out mechanisms have negative influence on the fiscal deficit (fiscal deficit decreases) and positive on public debt (public debt increases). By using the bail-out mechanism, fiscal positions of the economies are sustainable in relation to flow variable, while, the value of the stock variable, public debt, is deepening.

\subsection{Pandemic crisis}

The impact of the Covid-19 crisis, according to the European Commission's report, highlighted inequalities between EU members. Depending on the size of the economy and the preparedness of public finances, the state of the health care systems, as well as the dependence of economies on the currently most endangered sectors (tourism, catering), the gravity of the situation facing countries is reflected. Within the EU, a rapid and strong joint response to the Covid-19 crisis followed. According to Batini, Lamperti \& Roventini (2020), the European Commission has provided almost 4\% of GDP (EU-wide), amounting to EUR 540 billion to support crisis-affected economies. The aid package is divided into three segments: (i) the first aid package relates to health system support, and includes all health-oriented expenditures, and their funding is provided through the European Stability Mechanism (EMS); total availability of EUR 240 billion (which is half of the funds provided); (ii) a second aid package was earmarked to support companies, with a special focus on small and medium-sized enterprises (SMEs), under which EUR 25 billion was allocated through bank guarantees - to provide additional loans to companies worth EUR 200 billion; (iii) the latest aid package is aimed at combating unemployment, providing funds to protect workers and their jobs, with EUR 100 billion provided by guarantees from EU members.

The EU has taken another move in a bid to meet shaky economies. Instructed by the experience after the global financial crisis, as stated in the European Commission Report, The EU has decided to activate a general escape clause related to EU fiscal rules, allowing fiscal deficits exceeding the threshold of 3\% of GDP. By establishing Next Generation EU funds, the EU has shown solidarity and a desire to overcome adversity together, and along with the implementation of the Recovery and Resilience Fund (RRF) can emerge from the crisis not only as an economic winner, but also more stable ties within the community. According to the Report of the European Commission, the RRF grant should finance public expenditures in the form of investments, which would not jeopardize the public debt. We used data on the applied aid packages for Greece, Portugal, Spain and Ireland Stabilization Programme 2020 for each country, which was written at the level of nation states, within 
the Ministry of Finance. Detailed data about fiscal stimulus in 2020 in selected economies of the Eurozone are given in Table 4.

Table 4 Fiscal response to the Pandemic crisis in 2020

\begin{tabular}{|l|l|l|l|l|l|l|}
\hline Country & $\begin{array}{l}\text { Immediate } \\
\text { fiscal impulse }^{\mathrm{a}}\end{array}$ & Deferral $^{\mathrm{b}}$ & $\begin{array}{l}\text { Other } \\
\text { guarantee }^{\mathrm{c}}\end{array}$ & $\begin{array}{l}\text { Immediate } \\
\text { fiscal impulse }\end{array}$ & Deferrals & $\begin{array}{l}\text { Other guarantee } \\
\text { measures }\end{array}$ \\
\hline Greece & $3.1 \%$ & $1.2 \%$ & $2.1 \%$ & $€ 5.9$ billion & $€ 2.3$ billion & $€ 4$ billion \\
\hline Belgium & $1.4 \%$ & $4.8 \%$ & $21.9 \%$ & $€ 3.1$ billion & $€ 13$ billion & $€ 50$ billion \\
\hline France & $5.1 \%$ & $8.7 \%$ & $14.2 \%$ & $€ 124$ billion & $€ 210$ billion & $€ 342$ billion \\
\hline Netherlands & $3.7 \%$ & $7.9 \%$ & $3.4 \%$ & $€ 29.7$ billion & $€ 64$ billion & $€ 26.6$ billion \\
\hline Portugal & $2.5 \%$ & $11.1 \%$ & $5.5 \%$ & $€ 5.2$ billion & $€ 23.3$ billion & $€ 11.7$ billion \\
\hline Germany & $8.3 \%$ & $7.3 \%$ & $24.3 \%$ & $€ 284.4$ billion & $€ 251.0$ billion & $€ 832.1$ billion \\
\hline Italy & $3.4 \%$ & $13.2 \%$ & $32.1 \%$ & $€ 61.3$ billion & $€ 235.3$ billion & $€ 571$ billion \\
\hline Spain & $4.3 \%$ & $0.4 \%$ & $12.2 \%$ & $€ 53.8$ billion & $€ 5.3$ billion & $€ 151.2$ billion \\
\hline \multicolumn{7}{c}{ Note: ${ }^{a, b, c}$ Fiscal response is represented as a share of GDP in 2019. } \\
\end{tabular}

National governments have been quick to respond to the Covid-19 crisis with fiscal measures to support their economies. The Greek stimulus through the change in fiscal policy primarily amounted to EUR 5.8 billion, and it refers to the increase of budget spending and non-collection of certain taxes. Greece has also decided to defer certain taxes (VAT) and contributions, thus relieving the economy of 2.3 billion euros. To help maintain the economy's liquidity through guarantees, Greece has set aside 2.1\% of its 2019 GDP, which is 4 billion euros. The main beneficiaries of budget incentives, as stated in the Stabilization Plan of Greece, are companies in the private sector, employees, the selfemployed and freelancers. Portugal borrowed a similar amount as Greece (EUR 5.2 billion) for an instant response to the crisis, helping companies as well as the population individually. For deferred payments, taxes and loans, Portugal set aside almost 10 times more than Greece (EUR 23.3 billion). As regards measures aimed at maintaining liquidity, EUR 11.7 billion has been raised. Spain's expansionist policy was more generous than the previous two members. The Spanish government has set aside 4.3\% of GDP in 2019, representing EUR 53.8 billion in direct aid to the economy. EUR 5.3 billion was allocated for the moratorium on contributions, deferred tax debts, treatment of income tax and VAT. The largest funds (EUR 151.2 billion) were provided through guarantee schemes, which provide liquidity to the economy. Due to similar tax regulations (Tanasić, 2019), the Netherlands has decided to provide the greatest assistance to the economy through tax deferrals, by postponing the payment of corporate tax, personal income tax and value added tax (EUR 64 billion) for six months. Of all the countries observed, Belgium has both absolutely and relatively allocated the least funds for direct fiscal assistance to the economy (EUR 3.1 billion, i.e. 1.4\% of GDP in 2019). However, the Belgian government guarantees EUR 50 billion (which is $21.9 \%$ of GDP in 2019) for new additional loans with a maximum repayment period of 12 months. The French government has also decided to help the economy through various types of guarantee schemes, and EUR 342 billion has been raised for them (which is 2.5 times less than what Germany has set aside). Assistance in the form 
of deferred taxes, the credit moratorium amounts to EUR 210 billion, which is approximately the amount set aside by Germany for deferred payment of value added tax, corporate taxes, payroll taxes, income taxes and contributions (EUR 251 billion). Acharya et al. (2020) emphasize the importance of the banking system for overcoming the crisis caused by the Covid-19 pandemic. The authors point out the lesson learned from the financial crisis. After the express fiscal assistance, which is important in the short term, in the long run it will be necessary to have well capitalized banks since credits to both businesses and households will be essential. According to the analysis of bail-out programs in the pandemic crisis, we could conclude that policymakers of the Eurozone have learned some lessons from the global crisis and applied them in a pandemic crisis, namely, we could confirm the second hypothesis.

\section{Conclusions}

Given that the nature of past and current crisis is undoubtedly different, it is clear that it is impossible to completely replicate the financial instruments used so far as remedies against the current decline in economic activity. However, having in mind experiences from the global crisis, research shows that governments appear to have learned at least three lessons from the global crisis. First, government fiscal support measures have been implemented early as the economies entered the pandemic crisis, while in the case of a global crisis, a longer period of time was required until activation of bail-out mechanisms. Central banks have been quick in implementation of emergency measures, providing lower interest rates, while governments have been quick in implementation of fiscal stimulus measures. Faster and stronger reactions of fiscal and monetary authorities are the key weapons in a fight with pandemic crisis. Second, hopes that pandemic crisis would have fast recovery has disappeared, due to the fact that exogenous shock of coronavirus would cause endogenous shock in relation to the government debt. Namely, the both crises were transformed into a sovereign debt crisis, and central banks supported liquidity and held interest rates at low levels. From the fixed effects panel model, it could be concluded that bail-out mechanism was effective in reducing fiscal deficit for all observed economies, however, with negative impact on public debt for most of economies. Third, in the light of "new impossible trinity", no-bail-clause was abandoned in the case of global and pandemic crisis, although national fiscal sovereignty abandonment was the other solution. In both cases, strengthening the fiscal framework of the Eurozone economies by defining supranational fiscal rules remain the essence of a stronger Eurozone and the European Union.

\section{References}

Acharya, V., Borchert, L., Jager, M., \& Steffen, S. (2020, August). European bank bailout policies after the global fiscal crisis sowed seeds of the next crisis. Retrieved April 24, 2021 from https://european.economicblogs.org/voxeu/2020/borchert-jagersteffen-euro-area-bank-bailout-policies-global-financial-crisis-sowed-seeds-crisis

Bagus, P., Rallo, J., \& Neira, M. (2016). Bail-in or bail-out: the case of Spain. CESifo Economic Studies, 60(1), 89-106. Doi: https://doi.org/10.1093/cesifo/ifu009 
Batini, N., Lamperti, F., \& Roventini, A. (2020). Reducing risk while sharing it: A fiscal recipe for the EU at the time of COVID-19. International Monetary Fund, $\mathrm{WP} / 20 / 181$.

Beck, H., \& Prinz, A. (2012). The trilemma of a monetary union: another impossible trinity. Intereconomics, 47, 39-43. Doi: https://doi.org/10.1007/s10272-012-0404-0

Beker Pucar, E. (2020). The Nexus between FOF and Demand-Switching External Adjustment Mechanism: Emerging European and Latin American Floaters. Argumenta Oeconomica, 44(1), 47-77. Doi: https://doi.org/10.15611/aoe.2020.1.03

Department of Finance, Republic of Ireland, Economics Division. (2020). Stability Programme Update 2020 - Incorporating the Department of Finance's Spring Forecast. Retrieved April 24, 2021 from https://ec.europa.eu/info/sites/info/files/2020-europeansemester-stability-programme-ireland en.pdf

Didier, T., Huneeus, F., Larrain M., \& Scmukler, S. (2020). Financing Firms in Hibernation during the COVID-19 Pandemic. World Bank Group 9236.

European Commission. (2020). Communication from the Commission to the Council One Year since the Outbreak of COVID-19: Fiscal policy response.

European Commission. (2020). Council Recommendation on the Economic Policy of the EuroArea. Retrieved April 24, 2021 from https://ec.europa.eu/info/sites/info/files/2021 recommendation for euro area recomm endation.pdf

European Commission. (2020). Communication from the Commission to the Council on the Activation of the General Escape Clause of the Stability and Growth Pact. Retrieved April 24, 2021 from https://eur-lex.europa.eu/legal content/EN/TXT/PDF/?uri=CELEX:52020DC0123\&from=EN

Glavaški, O., \& Beker Pucar, E. (2020). Fiscal Consolidation in the EU-28: Multiyear versus cold shower episodes. Economic horizons, 22(1), 17-30. Doi: https://doi.org/10.5937/ekonhor2001017G

Government of Ireland, Department of the Taoiseach. (2020). National Reform Programme for the European Semester. Retrieved April 24, 2021 from https://ec.europa.eu/info/sites/info/files/2020-european-semester-national-reformprogramme-ireland en 0. pdf

Guillen, A. (2020). Coronavirus crisis or a new stage of the global crisis capitalism? Agrarian South: Journal of Political Economy, 9(3), 356-367. Doi: https://doi.org/10.1177/2277976020970040 
Gurnani, S. (2016). The Financial Crisis in Portugal: Austerity in Perspective. Lehigh University. $\quad$ Retrieved April 24, 2021 from https://preserve.lib.lehigh.edu/islandora/object/preserve\%3Abp-8425504

Helleiner, E. (2011). Understanding the 2007-2008 Global Financial Crisis: Lessons for Scholars of International Political Economy. Annual Review of Political Science, 14, 67-87. Doi: https://doi.org/10.1146/annurev-polisci-050409-112539

Iordanidou, S., \& Samaras, N. A. (2014). Financial Crisis in the Cyprus Republic. Javnost-The Public, 21(4), 63-76. Doi: https://doi.org/10.1080/13183222.2014.11077103

Kickert W., \& Ongaro E. (2019). Influence of the EU (and the IMF) on domestic cutback management: a nine-country comparative analysis. Public Management Review, 21(9), 1348-1367. Doi: https://doi.org/10.1080/14719037.2019.1618383

McDonagh, N. (2016). How to frame a bank bailout: lessons from Ireland during the Global financial crisis. Przestrzeń Społeczna (Social Space), 12(2), 84-112.

Ministry of Finance. Hellenic Republic. (2020). Stability Programme 2020. Retrieved April 24, 2021 from https://ec.europa.eu/info/sites/info/files/2020-european-semesterstability-programme-greece en.pdf

Ministry of Finance, Kingdom of Spain. (2020). Actualización Programa de Estabilidad 2020. Retrieved April 24, 2021 from https://ec.europa.eu/info/sites/info/files/2020-european-semester-stability-programmespain_en.pdf

Ministry of Finance, Portugal Republic. (2020). Stability Programme 2020. Retrieved April 24, 2021 from https://ec.europa.eu/info/sites/info/files/2020-european-semesterstability-programme-portugal_en.pdf

Mongelli, F. P. (2013). The Mutating Euro Area Crisis: Is the Balance between 'Sceptics' and 'Advocates' Shifting? ECB Occasional Paper 144.

Pagoulatos, G. (2019). Greece after the bailouts. Hellenic observatory papers on Greece and Southeast Europe, paper No. 130. Retrieved April 20, 2021 from https://www.researchgate.net/publication/336019715_Greece after the bailouts

Schuknecht, L., Moutot, P., Rother, P., \& Stark, J. (2011). The stability and growth pact, crisis and reform. European Central bank, No. 129. Retrieved on 21/04/2021 from https://www.ecb.europa.eu/pub/pdf/scpops/ecbocp129.pdf

Tanasić, L. (2019). Comparative overview of transfer pricing tax regulation in the world. The Annals of the Faculty of Economics in Subotica, 55(42), 111-127. Doi: https://doi.org/10.5937/AnEkSub1942111T 
Ullah, W. \& Parvez Ahmed, S. (2014). A review of European sovereign debt crisis: and consequences. International Journal of Business and Economics Research, 3(2): 66-71. Doi: https://doi.org/10.11648/j.ijber.20140302.13

Wilkes G. (2020, April). Bailout for business after coronavirus. Institute for Government UK. Retrieved April 18, 2021 from https://www.instituteforgovernment.org.uk/sites/default/files/publications/bailoutbusiness-after-coronavirus_0.pdf 
